М. А. Павленко, Д. О. Каліновський

Харківський національний університет Повітряних Сил ім. І. Кожедуба, Харків, Україна

\title{
АНАЛІЗ МЕТОДІВ ТА МОДЕЛЕЙ ПРИЙНЯТТЯ РІШЕНЬ НА УПРАВЛІННЯ ЧАСТИНАМИ ЗЕНІТНИХ РАКЕТНИХ ВІЙСЬК ТА ТАКТИЧНОЇ АВІАЦІЇ
}

\begin{abstract}
Анотація. У статті проводиться аналіз методів та моделей прийняття рішення в процесі управління частинами зенітних ракетних військ та тактичної авіації під час розподілу зусиль для знищення повітряного противника. Метою роботи є визначення ступеня впливу математичних апаратів методів математичного моделювання та їх інтеграцій, на формування альтернатив комплексу засобів автоматизації. Методологія проведеного дослідження включає емпіричний, теоретичний та загально логічні методи. Під час проведення дослідження виявлено властивість методів нечіткої логіки 3 підвищенням рівня складності моделі, а 3 нею і кількості правил, покращується ії можливість описувати реальні умови що дозволяє вирішувати завдання, коли традиційні методи неефективні, а саме відповідність вимогам які висуваються щодо обгрунтованості прийняття рішення та можливості отримання пояснення. Використовуючи класичну технологію прийняття рішення 3 відповідними методами і моделями можна прослідкувати їх взаємозв'язок на кожному з етапів. Тобто, за допомогою перехресної перевірки методів та моделей одна одною, так як в кожній 3 них $\epsilon$ переваги і недоліки. Використання вихідних даних одного методу як вхідних в наступному етапі і з іншим методом дає змогу не тільки перевірити вхідні данні а й збільшити кількість альтернатив. 3 іншої сторони взаємозв'язок можливо трактувати як наближений із за множини послідовностей використання методів і моделей на різних рівнях. Тобто в залежності від вибраної послідовності реалізації методів і моделей на кожному з етапів, можливо отримати різні множини значень. Практично підхід щодо виробки альтернатив прийняття рішення для розподілу зусиль між зенітними ракетними військами та тактичною авіацією може бути реалізований в комплексі засобів автоматизації за рахунок впровадження методів та моделей системи підтримки прийняття рішення.
\end{abstract}

Кл юч ов і слов а : прийняття рішення, метод аналізу ієрархій, нечіткі множини, нечітка логіка.

\section{Вступ}

Для вирішення задач пов'язаних з організацією та управлінням частинами зенітних ракетних військ та тактичної авіації, які виникають в процесі, спільної підготовки і застосування, виникає потреба в прийнятті управлінських рішень. Кожне таке рішення носить синергетичний характер, який без врахування попереднього досвіду може призвести до різних і не завжди позитивних наслідків (ризиків $[1,2])$.

Постановка проблеми. Під час прийняття управлінського рішення на розподіл зусиль щодо знищення повітряного противника між зенітними ракетними військами та винищувальною авіацією, перед особою яка приймає рішення (ОПР) постає необхідність в розв'язку багатокритеріальної задачі 3 використанням комплексу засобів автоматизації (КЗА). Тобто ОПР повинна вибрати таку альтернативу з множини сформованих КЗА, яка б задовільнила досягнення цілі і мети визначеного завдання. Для забезпечення адекватного функціонування альтернатив при розподілі інтелектуального ресурсу визначити достатній обсяг вхідної інформації з заданою достовірністю 3 врахуванням допустимих часових термінів, які необхідні для їі формалізації та використання. Створити умови які б дозволяли використовувати весь набір знань 3 логічним поясненням в залежності від поточної обстановки в реальному масштабі часу та у відповідності до заданого рівня ефективності. Тому з метою визначення степеню впливу кожного із методів рішення завдання, виникає необхідність розглянути теоретичне і практичне значення кожного з них.

Аналіз останніх досліджень і публікацій. Прийняття рішень в ході спільного застосування зенітних ракетних військ та винищувальної авіації здій- снюється в різних умовах 3 використанням множини параметрів, що потребує використання багатокритеріальних методів з автоматизацією процесу виробки рішення. Серед них, широке використання набули використання узагальнених критеріїв [3] 3 ваговими коефіцієнтами їх важливості [4], метод аналізу ієрархій (MAI) [5, 6], який оснований на попарному порівнянні альтернатив, теорії ігор [7], нечітких множин та нечіткої логіки [8, 9]. Проте необхідно визначити переваги їх використання саме під час прийняття рішення в процесі розподілу зусиль, щодо знищення повітряного противника зенітними ракетними військам та винищувальною авіацією.

Мета статті - полягає в дослідженні ступеня впливу математичних апаратів методів математичного моделювання та їх інтеграцій, на формування альтернатив КЗА.

\section{Виклад основного матеріалу}

Вироблення рішень під час підготовки та застосування військ (сил) супроводжується впливом різнорідних факторів, які діють на кожному з етапів формування рішення. Разом 3 тим необхідно враховувати зміни параметрів, які відбуваються в залежності від цих факторів. Тобто скільки часу фактор діє на параметр а відповідно і на етап і до яких наслідків призводить. Для висвітлення підходу щодо виявлення ступеню взаємозв'язку методів і моделей, які використовуються під час прийняття рішення на управління військовими частинами на кожному 3 етапів обрано класичну технологію прийняття рішення на основі трьох етапів:

- постановка завдання (діагностика проблеми);

- вироблення варіантів альтернатив;

- відбір та реалізація оптимального рішення (з погляду на відповідний критерій). 
Зазначимо, що є більш деталізовані моделі етапів прийняття рішення, які згадуються в роботах [10], проте формування загальної картини на основі цих моделей потребує визначення додаткових аспектів, які не будуть відображенні в даній публікації.

I етап (постановка задачі) характерний формулюванням цілей або їх сукупністю, які $є$ складовими елементами мети або самою метою. Він складається 3 таких кроків як: описання проблеми, збору інформації (факторів, які зумовили проблему) та аналіз інформації.

Формалізована модель застосування моделей та методів етапу "Постановка завдання" зображена на (рис. 1).

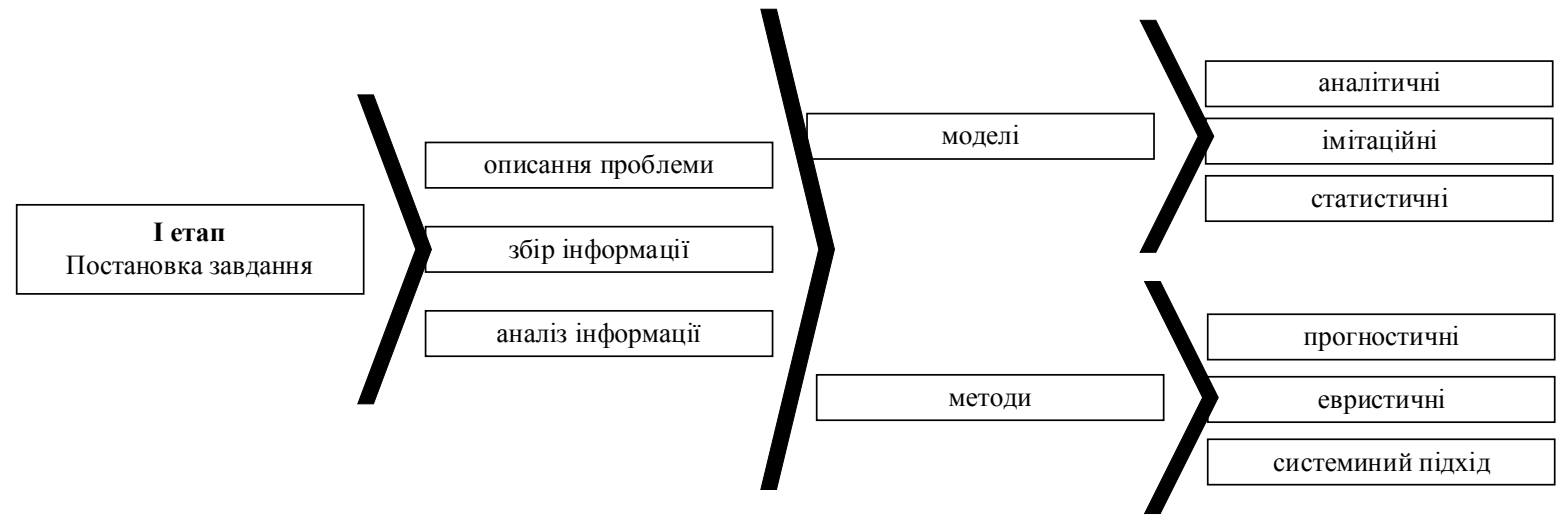

Рис. 1. Формалізована модель застосування моделей та методів етапу “Постановка завдання”

II етап (розробка альтернативних рішень) характеризується формалізацією знань у відповідності до інформаційного потоку 3 встановленням взаємозв'язків між отриманою інформацією і сформованими знаннями для автоматизації процесу вироблення рішення. Тобто, відбувається узагальнення отриманої інформації у відповідності до методології, яка реалізована в системі підтримки прийняття рішення з метою формування альтернатив на основі яких особа, яка приймає рішення зробить висновок і прийме рішення.
Складовими другого етапу “Вироблення варіантів альтернатив” є: обробка інформації, встановлення взаємозв'язків та формування альтернатив. Моделі які використовуються на даному етапі схожі 3 першим етапом, проте не враховуються моделі які використовуються для обробки даних, що значно розширить загальну картину процесу прийняття рішення тим самим збільшивши кількість зв'язків які необхідно дослідити. Формалізована модель етапу "Вироблення варіантів альтернатив” зображена на (рис. 2)

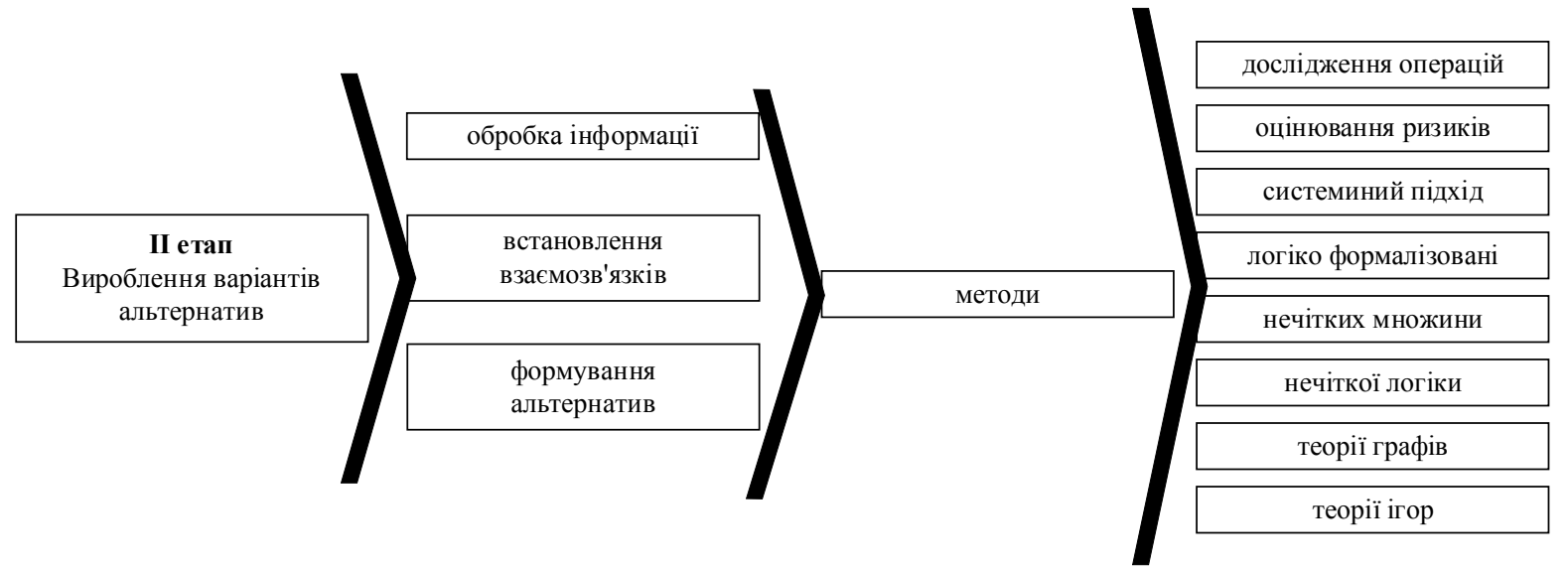

Рис. 2. Формалізована модель етапу “Вироблення варіантів альтернатив”

III етап (відбір та реалізація оптимального рішення) складається за таких кроків як: формування критеріїв, оцінка альтернатив, оцінка ефективності та прийняття рішення. Моделі і методи будуть схожі 32 етапом, тоді можна сказати що в залежності від вибраного методу і використання іiі на кожному етапі модель яка буде описувати весь процес прийняття рішення (включаючи організацію, оцінку прийняття рішення і наслідків його реалізації) буде будуватись ієрархічно, використовуючи результати попередніх розрахунків.

Переваги використання методів при вироблені рішення визначаються такими вимогами $[9,11]$ :
- можливості врахування показників ефективності виконання завдання;

- оперативності вироблення рішень;

- можливість врахування бойових можливостей та специфіки застосування;

- обгрунтованість прийняття рішення;

- можливості отримання пояснень;

- можливість врахування наслідків і ризиків.

Для визначення ступеню відповідності вимогам запропоновано розглянути основі аспекти методів, які використовуються в процесі прийняття рішення. Використовуючи наведений процес прийняття рi- 
шення підкреслимо, що складова формування критеріїв одночасно залежить від ряду факторів різного характеру. Тобто при дослідженні ми отримуємо значення різних параметрів з своїми критеріями (частковими критеріями). Об'єднавши часткові критерії в загальний критерій ми нівелюємо недостачу ефективності одного показника за допомогою компенсації $з$ іншими. Тому виникає парадокс в цінності критерія. Коли велика цінність критерію не відповідає його значущості [3]. В нашому випадку при оцінці бойових можливостей ми можемо компенсувати час підготовки до виконання завдання часом виходу на рубіж пуску. 3 іншої сторони можна побудувати систему зважених критеріїв у відповідності до існуючих методів 3 метою зменшення похибки розрахунків та/або виконати багатокритеріальну оптимізацію.

MAI в порівнянні з використанням узагальненого критерію можливо використати в складних умовах (невизначеній динамічній обстановці) використовуючи ієрархічну структуру розбитої на елементи системи 3 використанням суб'єктивних і об'єктивних оцінок експертів. Тому одним $з$ етапів проведення розрахунків слід оцінити достовірність оцінок експертів і провести узгодження [10]. Цей метод можемо застосувати для:

визначення альтернатив;

визначення часткових критеріїв та формування узагальнений;

визначення оперативності та обгрунтованості процесу прийняття рішення;

групування великої кількості параметрів (характеристик в кластери; графів.

інтерпретувати пріоритети за допомогою теорії

Ієрархічне зображення приведу на основі рішення задачі ефективності бойового застосування винищувальної авіації. Де перший рівень являється метою, другий рівень узагальненні показники, третій рівень часткові показники. Кожен узагальнений показник в свою чергу має свою групу часткових показників, проте кожен частковий показник може також входити і до інших груп. Рішення такої задачі являється одним 3 елементів системи підтримки прийняття рішення (рис. 3).

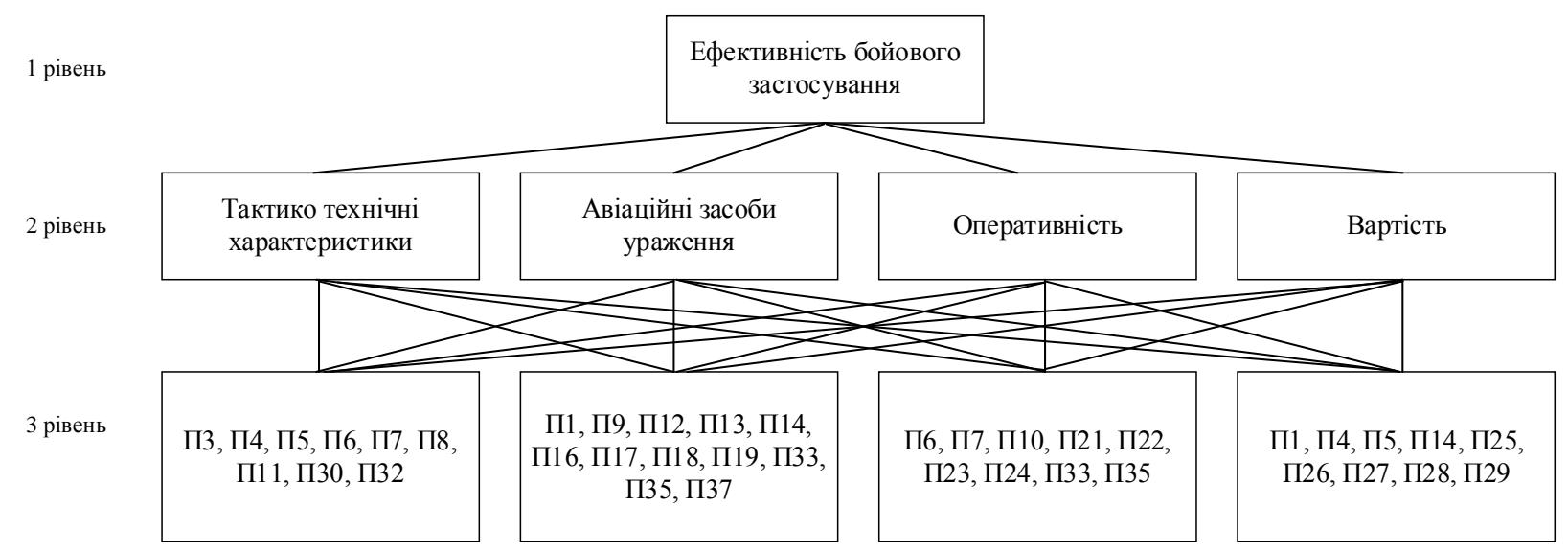

Рис. 3. Ієрархічне зображення задачі визначення ефективності бойового застосування

Тобто приведений метод дозволяє не тільки враховувати фактори які впливають на прийняття рішення, шляхом попарного порівняння, а й порівнювати альтернативи в залежності від своїх зв'язків, груп і рівня [11]. Проте даний метод не дає пояснень, що зумовлено присвоєнням вагових коефіцієнтів на основі особистої думки експертів, їхнього суб' єктивного бачення важливості.

Попередні методи передбачають прийняття рішення однією особою, яка несе за нього відповідальність. В теорії ігор на результат ігри впливають рішення декілька учасників, інтереси яких можуть бути різні. Кожен хід - це прийняття рішення, a їх сукупність це стратегія [12], яка реалізується для досягнення цілі. Прикладом може бути проведення двосторонньої гри 3 визначеними правилами, які визначають множину стратегій учасників а 3 іншої сторони наслідки і перемогу в результаті вибору кожної 3 стратегій. Проте створення оптимальної стратегії вимагає високих інтелектуальних і аналітичних здібностей а iї реалізація може рухнути при виникненні неврахованого фактору чи події на одному 3 кроків. Проте розгляд ієрархічної ігри [13] дозволяє розглянути послідовність ходів на основі яких можна побудувати ігрову модель 3 фіксованим порядком якого будуть дотримуватись обидві сторони при прийнятті рішень.

Використання нечітких множин, нечіткої логіки та нечіткого моделювання дозволяє вирішувати завдання, коли традиційні методи неефективні. Оперативність та обгрунтованість прийнятих рішень вимагає поєднання кількості та якості інформації починаючи 3 умов обстановки і завершуючи специфікою застосування визначених сил та засобів, які використовуються. Використовуючи попередні методи ми не можемо в повній мірі оцінити повноту та достовірність вхідної інформації. Тобто ще не провівши дослідження ми вже упустили показники критерія оцінки обгрунтованості прийнятих рішень [14]. Тоді навіть при експертній оцінці визначеної інформації виникає потреба в повторній оцінці при збільшені чи зменшені кількості факторів. Проте попередні методи мають місце в нечітких моделях, коли результати проведених розрахунків є частковим результатом діапазону прийняття визначеного рішення. Для прикладу стратегія $\mathrm{max} / \mathrm{min}$, яка використовується в теорії ігор має 
свою реалізацію в нечіткому виводі [15]. Проте використовуючи методи нечіткої логіки 3 підвищенням рівня складності моделі а 3 нею і числа правил або нечітких множин покращується ії можливість описувати реальні умови. Це дає нам змогу в залежності від діапазону рішень їх ієрархії і наслідкових зв'язків виділити властивість рефлективності прийняття рішення з визначеним ступенем достовірності.

\section{Висновки}

Використовуючи класичну технологію прийняття рішення з відповідними методами і моделями можна про-слідкувати їх взаємозв'язок на кожному 3 етапів. Тобто, за допомогою перехресної перевірки методів та моделей одна одною, так як в кожній з них $\epsilon$ переваги і недоліки. Використання вихідних даних одного методу як вхідних в наступному етапі і 3 іншим методом дає змогу не тільки перевірити вхідні данні а й збільшити кількість альтернатив. 3 іншої сторони взаємозв'язок можливо трактувати як наближений із за множини послідовностей використання методів і моделей на різних рівнях. Тобто в залежності від вибраної послідовності реалізації методів і моделей на кожному з етапів, можливо отримати різні множини значень. Практично підхід щодо виробки альтернатив прийняття рішення для розподілу зусиль між зеніт-ними ракетними військами та тактичною авіацією може бути реалізований в комплексі засобів автоматизації за рахунок впровадження методів та моделей системи підтримки прийняття рішення.

\section{СПИСОК ЛІТЕРАТУРИ}

1. Посохов І. М. Управління ризиками у підприємництві: навчальний посібник \І. М. Посохов. - Харків : НТУ «ХПІ», 2015. $-220 \mathrm{c}$

2. Гонтарева I. В. Управління проектами. Підручник / І. В. Гонтарева. - Харків: Вид. ХНЕУ, 2011. - 444c

3. Лотов А. В. Многокритериальные задачи принятия решений / А. В. Лотов, И.И. Поспелова. - М.: МАКС Пресс, 2008. $-198 \mathrm{c}$.

4. Ткаченко В. І. Теорія прийняття рішень органами військового управління: монографія / В. І. Ткаченко, Є. Б. Смірнов та ін. // За ред. В. І. Ткаченка, С. Б. Смірнова. - Х.: ХУПС, 2008. - 545 с.

5. Творошенко I.C. Технології прийняття рішень в інформаційних системах: навч. посібник. - Харків: ХНУРЕ, 2021. $120 \mathrm{c}$.

6. Раскин М. А. «Введение в теорию игр» // Летняя школа «Современная математика». - Дубна: 2008.

7. Соколовська 3. М. Математичне та комп’ютерне моделювання економічних процесів:[монографія ] 3. М. Соколовська, В. М. Андрієнко, І. Ю. Івченко [та ін.] - Одеса: Астропринт, 2016. - 272 с.

8. Taskin, Ahmet and Kumbasar, Tufan (2015), “An Open Source Matlab/Simulink Toolbox for Interval Type-2 Fuzzy Logic Systems”, 2015 IEEE Symposium Series on Computational Intelligence, pp. 1561-1568

9. Mendel J. M. Uncertain Rule-Based FuzzySystems / J. M. Mendel. - L. A.: University of Southern California, 2017. - 684 c.

10. Митрахович М. М. Беспилотные авиационные комплексы: Методика сравнительной оценки боевых возможностей / М. М. Митрахович, В. И. Силков, А.В. Самков, Х.В. Бурштынская, С.А. Станкевич, В.Б. Семенов. Под общей редакцией В.И. Силкова. - К.: ЦНИИ ВВТ ВС Украины, 2012. - 288 с.; 102 рис; 73 табл.

11. Загорка О.М. Багатокритеріальні методи прийняття рішень органами військового управління Анатолій Казимирович Павліковський (канд. військ. наук, доцент)Ірина Олексіївна Загорка Національний університет оборони України імені Івана Черняховського, Київ, Україна

12. Мулен Э. Теория игр с примерами из математической экономики. - М.: Мир, 1985

13. Губко М.В., Новиков Д.А. Теория игр в управлении организационными системами. Издание 2, М.: 2005.

14. Смірнов С. Б. Теоретичні основи формування та деградації складних організаційно-технічних систем : монографія / Є. Б. Смірнов, В.І. Ткаченко, І. В. Рубан, В.Г. Малюга, А.В. Тристан. - Харків : ФОП Панов А.М., 2008. - 162 с.

15. Пегат А. Нечеткое моделирование и управление / А. Пегат; пер. с англ.2е изд. М.: БИНОМ. Лаборатория знаний, 2013. 798 с.: ил. (Адаптивные и интеллектуальные системы).

Received (Надійшла) 23.06.2021

Accepted for publication (Прийнята до друку) 11.08.2021

\section{Analysis of methods and models of decision-making for managing of air defense missile troops and tactical aviation Maksim Pavlenko, Dmytro Kalinovskyi}

Abstract. The article analyzes the methods and models of decision-making in the management of anti-aircraft missile forces and tactical aircraft during the distribution of efforts to destroy the enemy air. The aim of the work is to determine the degree of influence of mathematical devices of methods of mathematical modeling and their integrations on the formation of alternatives to the complex of automation tools. The methodology of the study includes empirical, theoretical and general logical methods. The study revealed the properties of fuzzy logic methods with increasing complexity of the model, and with it the number of rules, improves its ability to describe real conditions, which allows to solve problems when traditional methods are ineffective, namely compliance with the requirements for decision-making and feasibility getting an explanation. Using classical decision-making technology with appropriate methods and models, you can trace their relationship at each stage. That is, by crosschecking methods and models with each other, as each of them has advantages and disadvantages. Using the output of one method as input in the next step and with another method allows not only to check the input but also to increase the number of alternatives. On the other hand, the relationship can be interpreted as approximate from a set of sequences of methods and models at different levels. That is, depending on the selected sequence of implementation of methods and models at each stage, it is possible to obtain different sets of values. In practice, the approach to developing decision-making alternatives for the distribution of efforts between anti-aircraft missile forces and tactical aircraft can be implemented in a set of automation tools through the introduction of methods and models of decision support systems.

Keywords: decision making, hierarchy analysis method, fuzzy sets, fuzzy logic. 